\title{
Discovering the Worlds of Life Sciences, Objects and Material in Nursery Schools: Teaching Practices and Training Proposals
}

\author{
By Frédéric Charles*
}

In French nursery schools ("l'école maternelle française"), primary school teachers take charge of the content organised into teaching areas of activities. The prescribed teaching activity "Discovering the world of life sciences, objects and material" refers to biology, physical sciences, chemistry and technology. The children's learning path concerning these worlds represents the early stages of the curriculum. Many research studied these children's learning (e.g. Bisault, 2005; Fleer, 1996; Ravanis \& al., 2013). This paper focuses on teachers and aims at describing and analysing the implementation of the practices of this early childhood education. In a curriculum perspective (Dillon, 2009; Martinand, 2003; Ross, 2000), an inquiry about the practices reported both in teachers' logs and questionnaires, reveals the contents, activities and issues associated with these educational experiences. The results show biology is privileged and preferred to technology by the teachers. The research indicates an interrelated scientific and technological curriculum and a science and technology mostly found, in what I called, "compositional schemes". The discovery of this world, through these compositional schemes, takes various positions according to the priorities assigned by the teachers. The research at last allows me to discuss the professional training of preschool teachers in order to improve the teaching practices in science and technology.

\section{Background and Issues}

In early childhood care facilities, French nursery school ("l'école maternelle française") is characterized by a clearly educational direction that has been taken since the fifties (Prost, 1981). Completely integrated into the school's structure (Ministry of National Education, 1989), nursery school (NS) is set by programs that define content organised into areas of teaching activities. This curriculum structure differs from the end of primary school (PS) or secondary school (SS), where identifiable and comparmentalized academic subjects exist.

${ }^{*}$ Associate Professor, S2HEP, University Claude Bernard Lyon 1, France. 
In the last prescribed curriculum (Ministry of National Education, 2008), the teaching area called "Discovering the world of the living science, material and objects" refers to the beginning of science and technology education (STE). The term "education" is preferred to the teaching of science and technology for these reasons (Bisault, 2011, p. 9):

- Firstly, the definition of the entity "science" is not obvious in nursery and primary schools.

- Secondly, there is not any science or technology teacher in these schools.

- Finally, the curriculum doesn't only content knowlegdes or skills: in science and technology, as in other fields besides, there are many contents related to educational activities.

Through these educational purposes, NS is the school that has to ensure a successful entry into scientific and technical culture (Orange \& Plé, 2000) contributing to the discovery of natural and artificial environment. The social and educational issues are fundamental, because NS is the first mean that provides training for almost all three to six year old children, in the current context of development of science and technology.

This training must offer the first experiential capitalization contributing to establishment of an empirical referent (Coquidé \& Lebeaume, 2003). These experiments have to be in according with the principles set by Pauline Kergomard $^{1}$. Maryline Coquidé (1998) clarifies the meaning of these first experiments: she places the NS as the place of practical familiarization. These experiences are mainly actions, sometimes real experiment. In building an empirical referent perspective, these educational experiences can be: realization of plantations in the school garden, building rolling objects or observation of the changing states of water. During NS years, these life experiences initiate the curriculum of science and technology at school. They consist of all meeting times between children and the world of science and technology.

This curriculum comes alive when supported by NS's teachers. This contribution aims at describing and analysing their professionnal acts. In France, these teachers are Master level graduate and professionals in teaching. The first part sets out references that allow me to investigate practices in STE. This curriculum perspective legitimates the research methodology, presented in the second part. The third part presents the results, including the discovery in what I suggest should be called "compositional schemes" and the preponderance of the dimension of weaving in professional actions.

\footnotetext{
${ }^{1}$ Pauline Kergomard (1838-1925) is the founder of the NS in France.
} 


\section{What are the Situations in Science and Technology Curriculum?}

\section{Academic Subjects, Subjects and Teaching Areas}

Christian Orange and Élisabeth Plé (2000) show researches concerned with PS are not the most frequent in science education studies. Even more blatant, those devoted to early education are restricted (Lasson, 2004; Ledrapier, 2007 Charles, 2012). The panorama of research on preschool shows a strong centering on teaching and learning process (e.g. Fleer, 1996; Ravanis, Christidou, Hatznikita, 2013) and the projection of SS organization on PS (Charles, 2008). Even if the label prescribed by the curriculum refers to academic subjects formed in French SS (Life and Earth Sciences, physics, chemistry and technology), in PS, and therefore in NS, these academic subjects are still a distant horizon. STE doesn't have the forms that can be taken by comparmentalized lessons in SS: there is no academic subject in PS and even less in NS.

Maurice Sachot (2004, p. 23) proposes "to completely avoid the use of the term "academic subject" in primary schools education. He shows how the model of academic subject, historically constituted in SS, and brought down to PS, is incompatible with the teaching provided in PS and NS. Joël Bisault (2011) joined this position. Analyzing STE in NS and PS, he considers it is necessary to deviate from the disciplinary logic and the projection of the SS organization on PS. In keeping with this way, Joël Lebeaume (2011, p 88) explains that the concept of academic subject is ambiguous in PS for three reasons:

- The first one is pedagogical: "Teaching is neither symbolized in NS and PS by well-identified teachers, nor by rooms nor specific equipments academic subject".

- The second reason is linked to curriculum: there is a "progressive differentiation that occurs in the course of education. For example, teaching area "discovering the world" in NS differenciates in PS with more focused math, science and technology lessons, and also history and geography. The process of disciplining is still partial in PS".

- The third is an epistemological reason and goes with the distinction between subject and academic subject: "Subject is a study area while academic subject refers to the results of these studies".

Thus, this research combines the academic subjects in SS and the matters in PS. These matters not yet incorporated in PS, do not exist a fortiori in NS, where contents are organised into teaching areas of activities.

This absence of academic subject, here postulated, appears during a day in NS. Indeed, the organization obeys a schedule that takes into account all teaching areas of activities, but Langage is the major aim of many lessons. 
However, Thérèse Thévenaz-Christen (2005), Bertrand Daunay and Isabelle Delcambre (2007) observe at the end of NS, that French lessons are characterized by the emergence of disciplinarity.

\section{Related Contents, Coherent Practices and Curriculum Perspective}

The structure of the curriculum pilots day's organization, the design of learning and teaching and teachers' interventions which are often related to specific times and locations (eg, rituals in a corner grouping, workshops around small tables): contents are interweaved.

Teachers' interventions constitute a "network of coherent practices" (Lebeaume, 1995, 2000). STE is connected with others educations. Teachers integrate different aims and teaching areas in the same lesson (Bisault, 2011).

Joël Lebeaume $(2000,2008)$ proves that French lessons and STE are connected by a relation I could call « connectivity ». He develops and expands this concept of connectivity, while distinguishing three registers: teaching, learning and curriculum.

By taking simultaneously topology, law and sociology, we suggest considering the connectivity as a link between lessons in interaction. These manifold links form a chain modeling curriculum followed by children and a coherent territory.

According to sociologists, these related contents belong to "the integrated code" (Bernstein, 1971) and to a "process-driven and child centered curriculum" (Ross, 2000). This curriculum with slighty marked external and internal borders, would be characterized by strongly interconnected activities. Thus, these activities would be more focused on children's familiar world. Teaching practices are networks that integrate STE in a complex system of activities and contents with changing priorities.

The STE curriculum is thought as a set of lessons referred to science and technology and interconnected by relations of cohesion and coherence (Bisault, 2011). Cohesion ensures continuity between two separate lessons and coherence allows a set of distinct lessons to contribuate to a same target: thus, the STE curriculum is interconnected to other curriculums.

Investigating the STE and its multiple interconnections implies diverging from research direction in science education studies and having a more holistic approach to the entire curriculum. In this curriculum perspective (Bisault, 2005; Dillon, 2009; Lebeaume, 2000; Martinand, 2003), our research aims at describing and analysing the implementation of the practices of this early childhood education.

\section{Methodology}

\section{Two Investigations}

The ambition to describe interconnected STE curriculum determines the choice of methodology for collecting data. Two inquiries about the practices were selected: 
- The first one is a qualitative approach (Coquidé, Le Tiec \& Garel, 2007) based on analysis of empirical data consisting in logbooks kept by 12 teachers during one year long. These data reveal the contents, activities and issues of STE. Indeed, the volunteers teachers had to relate their practice in these logs, between narrative and description of the perceived reality. These logbooks are highly personal and have the characteristics of a reflexive and professionnalizing writing (Cros, 2003). These logs allowed me to conduct 3 interviews per teacher (one interview every 8 weeks). Interviews were used to explore the missing parts of STE curriculum and its interconnections with other teaching areas of activities.

- The second investigation is a quantitative approach based on a questionnaire. The analysis of practices reported by 92 teachers allows me to refine trends identified by the first approach. These teachers participated in a training congress held in Annecy (France) from 1 to 3 July, 2010. The combination of logs, interviews and questionnaire, whose content were fully transcribed, restores the practices.

\section{Method of Analysis}

In a curriculum perspective, analysis uses a grid that focuses on three dimensions:

- The first one, according to Lebeaume (2000), characterizes the lessons of STE, including contents, activities and issues associated with these educational experiences.

- The second dimension, inspired by Lenoir (2008), characterizes relations between STE and other educations with a synchronic vision. These relations can be relations of dominance, sharing, etc.

- The last dimension captures the position of STE over time, in a diachronic perspective.

This grid is used to reconstruct the STE curriculum, its vertical relation in programming and implementation over time, and horizontal relation with other educational curriculums.

\section{Results}

Biology Privileged and Preferred to Technology

The research gives quantitatively contents supported by teachers (see Table 1). 
Table 1. Worlds Supported by Teachers

\begin{tabular}{|c|c|}
\hline Which world do you take charge? & $\begin{array}{c}\text { Number of teachers } \\
\text { (12 followed) }\end{array}$ \\
\hline Life & 10 \\
\hline Material & 8 \\
\hline Objects & 3 \\
\hline
\end{tabular}

The results show that some parts of the discovery of the world are very present, and some others absent: teachers prefer the living world, the world of objects is left in the shadow: biology is privileged and preferred to technology. The world of material occupies an intermediate position. These results converge with others (Baillat, 2001; Lasson, 2004). They show that technology is reduced in NS and that teachers give priority to biology.

\section{A Curriculum in Interrelations}

The result of one question ${ }^{1}$ in my questionnaire shows the STE does not form a separate curriculum (see Figure 1).

Figure 1. Teacher's Answers on the Relationship between STE and other Educations (In Percentages)

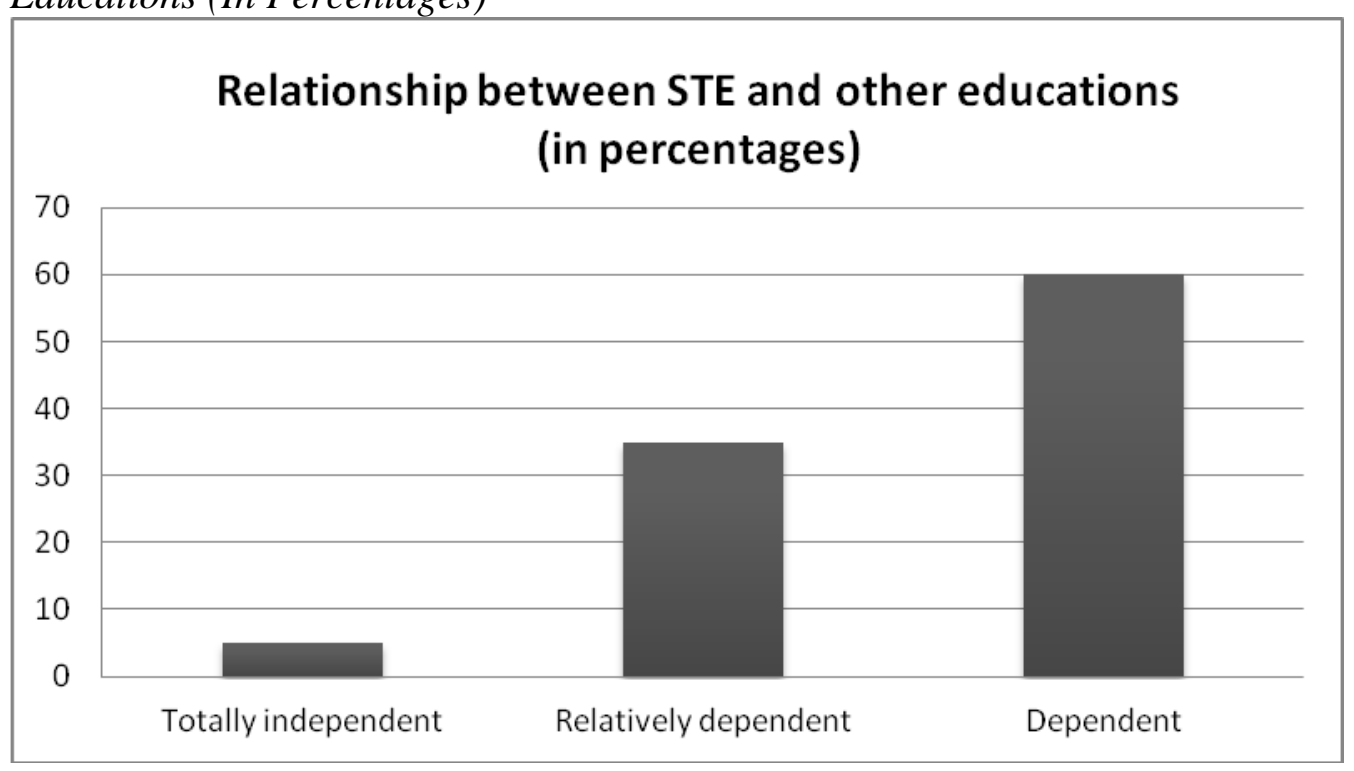

Moments constituting the STE curriculum are 95\% dependent from other education courses. This connectivity shows that STE is a curriculum in multiple interrelations set in what I suggest to call "compositional schemes".

\footnotetext{
${ }^{1}$ For this question, select the answer that best fits with your practice: when you teach "discovering the worlds of life sciences, objects and material":

- Teaching is completely independent of a project or a topic that you lead.

- Teaching is relatively dependent of a project or a topic that you lead.

- Teaching is related to a project or a topic that you lead.
} 


\section{Conceptual Proposal: Compositional Schemes}

These compositional schemes are observed with 11 of 12 teachers followed with logbooks. The concept of "composition" is developed by using an example. The teacher Sophie implements in its class (3-4 years old children), one composition labeled "penguins and auks" which here is a brief synopsis:

From two photographs showing both animals and their differences (from North and South Poles), Sophie develops a composition in which all classroom activities revolve around this theme (count penguins, make penguin mask, work on letters word P, E, N, G, U, I and N, etc.). (Synopsis of «Penguins and auks» composition)

When teaching "discovering of the world", Sophie seeks the designation and recognition of two species, Penguin and Auk, by combining their respective polar media.

All teaching activities are present in this compositional scheme: indeed, Sophie relates all activities to these two representatives of the animal world:

Graphics: Color the letters that form "penguin".

Scripture: slacks A, E, F, a, e, u, and the word "penguin", the phrase "penguins live at the North Pole".

Oral and written language: find the letters of the word "penguin".

Phonology: the sound [o] (as in Penguin ${ }^{1}$ ) and its various writings.

Literature: rhymes about penguins.

Mathematics: Counting penguins; Pasting the good number of penguins requested.

Discovering the world: Distinguishing the North Pole from the South

Pole, life sciences at the poles.

Visual arts: Mask of Penguin; manufacture of a Penguin with milk

bottles.

Sport: motility in connection with the penguin's march.

Music: "A penguin at the North Pole".

(Extract from Sophie's log)

This example highlights that contents are related and practices crosslinked. They give birth to "compositional schemes" consisting of a set of different school lessons forming a coherent whole. In addition to these initial characteristics, the composition is characterized by its adaptability. Indeed, starting with a moment of collective language in which Sophie presents two animals pictures, it is chance that determines the following: the teacher changes the general organization of the composition: a pupil brings a globe and then, a detailed work on the poles is carried so much larger than originally planned.

\footnotetext{
${ }^{1}$ Pinguin is translated by the world "Manchot" in French.
} 
The composition is adapted here to make a preponderant part of the discovery of the world, the trails in the areas:

Sophie: Initially, I thought teach penguins with their animal side, but suddenly I changed my orientation because a child gave me a globe and... Suddenly, we went to geography, to North and South Pole. In addition, on this globe, there were animals drawn on different continents, and although we worked on the continents, these animals, and of course North Pole/South Pole. So we spent two days searching continents, seas and oceans. (First interview with Sophie)

Therefore, a compositional schemes is a dynamic set, which has an initial structure provided by teachers, from which may arise a set of variations. Composition is like a pattern, a grid, written and thought in advance which is deformable in action: the teacher, as a dancer or a jazz player, can freely improvise.

\section{Different Ways to Handle the STE Curriculum}

We can suggest 4 different ways of handling the STE curriculum with data analysis. Within the compositional schemes, the STE takes various positions according to the priorities assigned by the teachers.

\section{No Support for STE Curriculum}

The compositions are marked by a STE placed in a minor position, with no real scientific target. Teacher's statements indicate confusion, as the label program is included with the idea of active discovery of the world, without specifying neither scientific nor technological aspects. This is the case for two teachers and in this example in a composition called "firemen":

Delphine: I conducted a "firemen" project in May. In "Discovering the world", my targets are:

- Visit to fire station.

- Discovery of firemen's equipment.

- Identify, classify, categorize, and describe objects, their attributes and their uses: helmets, gloves, lights, ladders and vehicles.

\section{(Extract from Delphine's log)}

For these teachers, there is no real STE support. The curriculum is marked by ephemeral meeting activities with the world of science and technology. Moments of STE are often used as a pretext for highest targets such language or visual arts. Teacher Élise, for example, uses "discovering the world" in an aesthetic perspective: construction games that could allow a technological target, is used to carry out artistic activities: 
Élise: Meanwhile, children with cubes, they have to make constructions. In relation with books on kings and queens, I told them that we could build castles and towers. The children were building...

Researcher: I think I did not understand everything. What do you call in your logbook "The Castle"? Can you explain to me? What was important in the construction of these towers: to build higher, bigger? Can you tell me more, please?

Élise: No that was not important. It was not at all important. Here, it was the same; it was a target of visual arts. All this allows me to make visual arts.

(Second interview with Élise)

\section{Cohabitation and Practical Familiarization}

The majority of teachers think STE within compositional schemes (7 out 12 followed with logbooks). These teachers succeed in their professionnal acts to cohabit different targets in different educations. They develop children's practical familiarization with the world of science and technology, through an active discovery of things and phenomena. Thus, teachers contribute to children's experiential enrichment but without a real intellectual development:

Discovering the world of material:

My target is to make children experiments with water around the problem: "how to carry water from one object to another?"

(...)

5 January 2010: pupils experience using the syringe to carry water.

(Extract from Carine's log)

Two types of balancing priorities are observed:

- Within the compositional schemes themselves: there is no hierarchy in the priorities given to contents.

- During the time compositions succeed: STE is considered in terms of programming time and then occupies a more or less central position in compositional schemes.

\section{Disciplinary Emergence and Intellectual Development}

Teachers implement in compositions, activities marked with a disciplinary target. These teachers (4 out 12) focus on knowledges or skills that are specific 
to scientific or technological academic subjects. Professionnal acts show that these teachers not only aim at enriching experience but also at acquiring more formalized knowledges on the scientific and technological world. These teachers both value practical familiarization and intellectual development. This is the case for example in Amélie's work on the world of the living from farming insects. Amélie aims not only at developing the attitudes of care and respect in relation to life, but also at gaining knowledges about the concept of living and specific skills about scientific observation:

Discovering the world of the live sciences: farming stick insects and butterflies.

My targets are: watch events in the life of insects and explore the lifecycle (birth, growth, reproduction, aging and death).

(...)

For the activity today, I gave to the children a magnifying glass and observation pots. Then I asked them to draw the best possible four kinds of eggs. Some children are reluctant in their design: I encourage with explaining them to draw what they see.

\section{(Extract from Amélie's log)}

\section{To a Separate STE Curriculum}

Only one teacher supports STE completely independently of other courses. Jean-Philippe implements STE marked not only by disciplinary emergence described above but also a STE curriculum separate from others. The extract of an interview with Jean-Philippe is particularly interesting: the only man of volunteers teachers says he does not practice like his colleagues. While knowing and explaining standarts characterizing professional acts in PS, JeanPhilippe rejects deliberately these standarts.

Jean-Philippe: there are many teachers in PS who work... everything is related to the same theme. I don't like this... I don't like working like that. I never work by theme, I don't like. For example, in October, I won't link all my courses to Halloween: talk about pumpkin, work with the orange color, and count skeletons... So actually, I have my programming time in phonology, mathematics, and science...

When I'm joining a training course with colleagues, they all practice the same way, with these themes. I know it's a tradition in PS. It's traditional, all my colleagues of training center, they all do with these themes. Even in the training center, trainers made us work like this, with a central theme or project.

\section{(Third interview with Jean- Philippe)}




\section{Training Proposals}

This research, which aimed at describing and analysing professional acts, has promoted a comprehensive approach to STE curriculum. It has revealed the contents, activities and issues associated with this curriculum. The results indicate an interrelated STE mostly found in compositional schemes. Thus, the design of the composition and its implementation are identifiable events in NS teachers' professional acts. Composition is a specific standart in NS culture. These elements fundamentally question the training curriculum of the NS teachers who are in charge of the STE.

In keeping with Jean-Louis Martinand's opinion (1995), I believe that the STE both aims at contributing to children's experiential enrichment, by changing their conceptual view about things and phenomena. The results of this investigation show that the practices do not generally tend to these principles.

In France, training takes place in universities and teachers must have a Master degree to teach in NS. Following Maryline Coquidé (2007), this research allows me to discuss the professional training of NS teachers in order to improve the teaching practices in science and technology. This training should have to take account of the difference between:

- The described reality of professional acts and therefore, the existence of compositional schemes.

- The need for an education with epistemological coherence.

The predominance in professional acts of a weaving dimension (Bucheton \& Soulé, 2009) ensures the cohesion between STE and other educations but constitutes an obstacle for teachers to think the coherence in STE. Thus I can deduce a list of training proposals:

- This course should take account of the interrelated nature of STE. This specificity requires a renunciation of a training thought as a multivalency and a downward projection of SS academic subjects (the different valencies) on PS where they do not exist. The training would aim at developing the teachers' skills in order to take charge a STE that they can really handle.

- Science education studies should have a central place as a training subject. Science education studies refer to three dimensions: psychological, pedagogical and epistemological dimensions. In keeping with Joël Bisault's opinion (2011), I suggest to think STE not only in terms of knowledges but also in teachers' practices and children's activities. Why not start from what pupils can really do and not from what they should learn?

- This training should be entrusted to multi-categorial teams, to science education studies' different orientations and incarnations: 
University trainers, NS trainers and researchers. Thus, the trainers would not juxtapose their skills but would share them: these teams would have to work together to define possible meeting activities between children and science and technology. These meetings times are a possible entry for thinking STE. They would not only be an acquisition of knowledges or procedures, but also confrontation of pupils with objects (natural or artificial, like vacuum, balloon, punch) and phenomena, to change their point of view about them.

These suggestions, based on the STE curriculum can also be extended to other areas of teaching activities. Therefore they may contribute to the NS teachers training: so many things are played between the age of 2 and 6 that it is absolutly necessary to train teachers in early childhood education.

\section{References}

Baillat, G. 2001. Enquête sur la polyvalence des enseignants du premier degré. Research Report. Université de Reims Champagne-Ardenne.

Bernstein, B. 1971. On the Classification and Framing of Educational Knowledge. In Knowledge and Control, New Directions for the Sociology of Education, M. Young, Ed. Collier-MacMillan, London, 47-69.

Bisault, J. 2005. Langage, action et apprentissage en sciences à l'école maternelle. Spirale. 36, 123-138.

Bisault, J. 2011. Contribution à l'élaboration curriculaire d'une éducation scientifique à l'école primaire: modélisation des moments scolaires à visée scientifique. Ph.D. diss. École Normale Supérieure de Cachan.

Bucheton, D. and Soulé, Y. 2009. Les gestes professionnels et le jeu des postures de l'enseignant dans la classe: un multi-agenda de préoccupations enchâssées. Éducation \& Didactique. 3, 3, 29-48.

Charles, F. 2008. La première education scientifique et technologique des enfants de deux à sept ans. Mémoire bibliographique de Master Recherche. École Normale Supérieure de Cachan.

Charles, F. 2012. Découvrir le monde de la nature et des objets avant six ans à l'école maternelle: spécificités du curriculum, spécialité des enseignants. Doctoral Thesis. Université de Paris Descartes, La Sorbonne.

Coquidé, M. 1998. Les pratiques expérimentales: propos d'enseignants et conceptions officielles. Aster. 26, 109-13.

Coquidé, M. 2007. Quels contenus de formation pour enseigner à l'école maternelle? L'exemple de la formation à l'activité "faire découvrir la nature et les objets". Recherche et formation. 55, 75-92.

Coquidé, M. and Lebeaume, J. 2003. La découverte de la nature et des objets à l'école, hier et aujourd'hui. Grand N. 72, 105-114.

Coquidé, M., Le Tiec, M. and Garel, B. 2007. Exploiter des espaces pour découvrir la nature et les objets. Éléments de professionnalité enseignante de cycles 1 et 2 . Aster. 45, 17-28.

Cros, F. 2003. L'écriture sur la pratique est-elle un outil de professionnalisation? Perspective documentaires en éducation. 58, 41-47. 
Daunay, B. and Delcambre, I. 2007. Les rituels en maternelle. Genre scolaire ou disciplinaire? Les cahiers THÉODILE. 7, 33-48.

Dillon, J.-T. 2009. The questions of curriculum. Journal of Curriculum Studies. 41, 3, 343-359.

Fleer, M. 1996. Early learning about light: mapping preschool children's thinking about light before, during and after involvment in a two weeks teaching program. International Journal of Science Education. 18, 7, 819-936.

Lasson, C. 2004. Ruptures et continuités dans la familiarisation pratique en technologie de l'école pré-élémentaire au collège. Doctoral Thesis. École Normale Supérieure de Cachan.

Lebeaume, J. 1995. La transformation des travaux d'aiguille en leçons de couture ou la constitution d'un réseau de pratiques cohérentes. Spirale. 14, 103-136.

Lebeaume, J. 2000. L'éducation technologique. Histoire et méthodes. Paris, ESF.

Lebeaume, J. 2008. L'enseignement des sciences à l'école. Des leçons de choses à la technologie. Paris, Delagrave.

Lebeaume, J. 2011. Les choses et les mots à l'école. Exploration de la connexité des enseignements de français et de sciences (1880-2000). Carrefours de l'éducation. $1,87-100$.

Ledrapier, C. 2007. Le rôle de l'action dans l'éducation scientifique à l'école maternelle: cas de l'approche des phénomènes physiques. Doctoral Thesis. École Normale Supérieure de Cachan.

Lenoir, Y. 2008. L'interdisciplinarité dans l'enseignement scientifique: apports à privilégier et dérives à éviter. In Interdisciplinarité et enseignement scientifique et technologique, A. Hasni and J. Lebeaume, Ed. Éditions du CRP et INRP, Sherbrooke et Lyon, 17-32.

Martinand, J.-L. 1995. Pour la pratique des sciences et de la technologie. Idées directrices pour penser les sciences et la technologie à l'école. In Découverte de la matière et de la technique, J.-L. Martinand, Ed. Hachette, Paris, 5-16.

Martinand, J.-L. 2003. L'éducation technologique à l'école moyenne en France: problèmes de didactique curriculaire. Revue canadienne de l'enseignement des sciences, des mathématiques et des technologies. 3,1, 101-106.

Ministry of National Education (1989). Bulletin Officiel. 9 (Aug. 1989).

Ministry of National Education (2008). Bulletin Officiel. 2 (Feb. 2008).

Orange, C and Plé, É. 2000. Les sciences de deux à dix ans. L'entrée dans la culture scientifique. Aster 31, 1-8.

Prost, A. 1981. Histoire générale de l'enseignement et de l'éducation en France, tome 4. Paris, Nouvelle Librairie de France.

Ravanis, K., Christidou, V. and Hatzinikita, V. 2013. Enhancing conceptual change in preschool children's representations of light: a socio-cognitive approach. Research in Science Education. 43, 6, 2257-2276.

Ross, A. 2000. Curriculum: construction and critique. London/New-York, Falmer Press.

Sachot, M. 2004. Disciplines du maître, disciplines de l'élève: contre une "disciplinarisation" du primaire. In Les enseignants $d u$ primaire entre disciplinarité et interdisciplinarité, M. Sachot and Y. Lenoir, Ed. Presses Universitaires de Laval, Laval, 19-33.

Thévenaz-Christen, T. 2005. Les prémices de la forme scolaire. Étude d'activités langagières orales à l'école enfantine genevoise. Doctoral Thesis. Université de Genève. 
